\title{
Vibrations diagnostics and analysis in operator's and passenger cabins of a suspended monorail
}

\author{
Kamil SZEWERDA ${ }^{1}$ *, Jarosław TOKARCZYK ${ }^{1}$, Pavol BOŽEK ${ }^{2}$, Dariusz MICHALAK ${ }^{1}$ \\ and Andrzej DRWIEGA ${ }^{1}$
}

Authors' affiliations and addresses: ${ }^{1}$ KOMAG Institute of Mining Technology, Laboratory of Modelling Methods and Ergonomics, Pszczyńska 37, 44-101 Gliwice, Poland

e-mail: kszewerda@komag.eu

${ }^{2}$ Slovak University of Technology in Bratislava Faculty of Materials Science and Technology Institute of Production Technologies

Slovakia

e-mail: pavol.bozek@stuba.sk

\section{*Correspondence:}

Kamil Szewerda, KOMAG Institute of Mining Technology, Laboratory of Modelling Methods and Ergonomics, Pszczyńska 37, 44-101 Gliwice, Poland

tel: +48322374531

e-mail: kszewerda@komag.eu

\section{Acknowledgement:}

The paper was written as part of the work carried out under the European project INESI, "Increase efficiency and safety improvement in underground mining transportation routes". This project is financially supported by the Research Fund for Coal and Steel under the Grant Agreement No 754169.

Calculations were carried out at the Academic Computer Centre in Gdańsk, Poland

How to cite this article:

Szewerda, K., Tokarczyk, J., Božek, P., Michalak, D. and Drwięga, A. (2020).

Vibrations diagnostics and analysis in operator's and passenger cabins of a suspended monorail. Acta Montanistica Slovaca, Volume 25 (2), 150-158

DOI:

https://doi.org/10.46544/AMS.v25i2.2

\begin{abstract}
One of the negative factors affecting operators and passengers of suspended monorails moving to their workplaces are the vibrations that act on the entire human body. These vibrations are related to the design of the suspended monorail and the route on which it moves. Excessive exposure to this negative factor adversely affects the human body. The results of numerical simulations aimed at comparing the vibration level during travelling along a straight section of the route, in which the operator's cabin and passenger cabin were rigidly connected to the trolley and innovative design in which yielding suspension was introduced are presented. Such damping of vibrations acting on passengers significantly improves the safety and comfort of miners in underground mining plants. Application of the computational model presented in the article and the method of analysing the results of the simulation enables optimal selection of materials with appropriate damping characteristics. A properly selected vibration damping system increases the comfort of the operator and transported people, and may become an element of competitive advantage when benchmarking transportation systems with the same operating parameters. The application of the proposed approach allows us to optimise, in terms of costs, the selection process of the optimal damping system, thanks to the possibility of verification of various damping parameters, without the necessity to investing in the real components and performing a real test, but only based on the results of the multibody simulation. The use of these numerical simulations is an example of a modern way of supporting the design and perfecting processes of state-of-the-art machines used in underground coal mines.
\end{abstract}

\section{Keywords}

mining, suspended monorails, vibrations, numerical analysis, dynamics, multibody simulation, exposure to vibrations, virtual prototyping 


\section{Introduction}

A suspended monorail is one of the main means of auxiliary transportation in underground hard coal mines is. The suspended monorail is usually propelled by its own drive, which are diesel engines or electric motors, and the whole train moves over the rail fixed to the roof support arches. This type of transportation has many advantages, such as increased safety, the comfort of use or no need to maintain the floor and the track in the proper condition. However, research work is continuing to improve and extend the existing solutions. Innovations introduced in the design of suspended monorails are aimed at improving comfort, safety and increasing the permissible speed during transportation of people (Budniok et al., 2014; INESI, 2019; Tokarczyk, 2017; Zasadni et al., 2015; Lesiak and Brzeżański, 2018; Tokarczyk and Kania, 2016). Intensive work in this area is carried out within the INESI project coordinated by KOMAG (INESI, 2019; Pieczora and Suffner, 2017; Polnik, 2018). As part of the project, survey research for operators and passengers of suspended monorails were carried out to assess the current conditions and development trends regarding sub-assemblies of suspended monorails (Bozek et al., 2016). In these surveys, about $56 \%$ of surveyed operators of suspended monorails stated that vibrations in the operator's cabin are unfavourable (13.64\% of respondents) or very unfavourable $(39.39 \%$ of respondents). The suggestion to modify and improve vibration damping system in the operator's seat was assumed as important by $30.30 \%$ of the surveyed operators, while as very important by $40.91 \%$ of the surveyed operators. Thus, $71.21 \%$ of operators consider reducing the impact of vibrations while driving as a very important aspect of the development of the suspended monorail design. Moreover, $63.64 \%$ of operators considered a modification of suspension of the entire operator's cabin as important (19.7\% of respondents) or very important (43.94\% of respondents). The same questions were asked, in a separate survey, to people who were carried in passenger cabins. In this case, $34.71 \%$ of surveyed passengers travelling in suspended monorails found that vibrations have a large $(23.97 \%)$ or very large $(10.74 \%)$ negative impact on the comfort of travelling in the passenger cabin. However, the concept of reducing the impact of vibrations on the seats was considered to be important or very important by $42.98 \%$ of passengers. Modification of suspension of the passenger cabin was considered to be important or very important by $44.62 \%$ of passengers $(22.31 \%$ - very important, $22.31 \%$ important). Based on the surveys, it can be stated that vibrations adversely affect both operators and passengers of the suspended monorails, significantly reducing the comfort of work (INESI, 2019). It should be noted that vibrations are also a risk factor at the workplace and excessive exposure to this factor may have its health consequences (Kowalski and Zając, 2017; Kowalski and Zając, 2012; Kiełbasa and Juliszewski et al., 2017; Bovenzi 2005; Krajnak 2018; Basri and Griffin 2013; Muravev et al., 2019). Maximum allowable exposure to vibrations during a work shift as well as the method of measuring and calculating the daily exposure at the workplace are specified by the regulations and standards (PN-EN 14253+A1:2011; Dz.U. 2018 poz. 1286; Nędza et al., 2006). Regular exposure to excessive vibration can have adverse health effects, such as reduced concentration, poor mood or the vibrational syndrome, which in many countries, including Poland, is considered as a professional disease. The biggest irritation of the labyrinth and the strongest vibration sensation occurs for the frequency of the vibrations up to $35 \mathrm{~Hz}$. This is related to the resonance of each organ (Harazin, 2002; Kiełbasa et al., 2019; Kowalski, 2019; Szczepaniak and Kromulski, 2011; Koradecka, 1999; AlShabi et al., 2016; Issever et al., 2003).

In the light of ongoing work aimed at increasing the permissible speed of suspended monorails while moving people, it seems very important to minimise vibrations and overloads that affect both the operator and the suspended monorail passengers (Budniok et al., 2014) Reduction of total vibrations is especially important. For this purpose, in the INESI project, the suspension of the operator's cabin was modified, and the damping inserts with appropriate stiffness were selected. A new cabin design was also developed, where a flexible suspension was used (INESI, 2019; Szewerda, 2019; Tokarczyk et al., 2019). This article presents a computational model of a suspended monorail, used to simulate and compare vibrations affecting the operator and passengers during travelling along a straight section of a route in the case of a rigid connection of cabins with trolleys and in the case of yielding suspension components. This model enables verifying the correct operation of the components that dampen vibrations affecting both the comfort of work and its safety.

\section{Material and Methods}

The computational model of the suspended monorail, used during numerical simulations, consisted of operator's cabin, machine part, two rack and pinion drives, cabin for people movement and a braking trolley. This transportation set moved on a track constructed of a new type of straight $4 \mathrm{~m}$ long rails, hanging on suspensions by means of transverse traverses (Figure 1).

Within the project, two variants of the computational model were developed to compare the vibration and overloads acting on both the suspended monorail operator and the passengers. In variant 1 , both the operator's cabin and the passenger cabin were rigidly connected to the trolleys. In variant 2 , the system damping the vibration and reducing overloads acting on the operators and passengers of the suspended monorail was 
modelled. In the case of operator's cabin, four elastic-damping components connecting the cabin with the trolley from the top and four elastic-damping components connecting the cabin with the trolley from the bottom (Figure 2) were introduced. These components replaced elastic inserts used in the design of cab suspension. Analysis of stiffness parameters of those components was carried out in the previous research projects, the results of which were presented in (Szewerda, 2019).

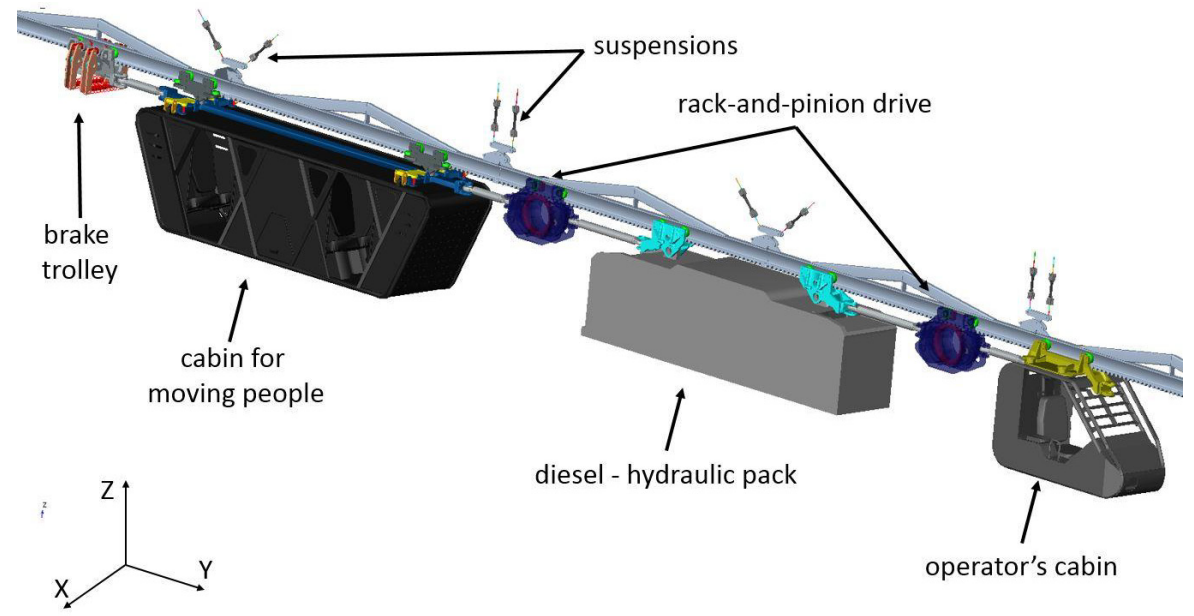

Fig. 1. A computational model of the suspended monorail (INESI, 2019)

The "upper" elastic-damping components were compressed, and they transferred main loads during operation. In the computational model, their stiffness $1.64 \cdot 10^{6} \mathrm{~N} \cdot \mathrm{m}^{-1}$ and a damping factor of $1.5 \cdot 10^{4} \mathrm{~N} \cdot \mathrm{s} \cdot \mathrm{m}^{-1}$ were assumed. The "lower" elastic-damping components task is to protect the operator's cabin against its direct hit on the trolley in the result of dynamic phenomena and deflection of the upper damping components. In the calculation model, the following parameters were adopted in relation to "lower" elastic-damping components: stiffness equal to $10 \mathrm{~N} \cdot \mathrm{m}^{-1}$ and damping factor equal to $4000 \mathrm{~N} \cdot \mathrm{s} \cdot \mathrm{m}^{-1}$. The difference between variant 1 and 2 regarding the operator's cabin is shown in Figure 2.

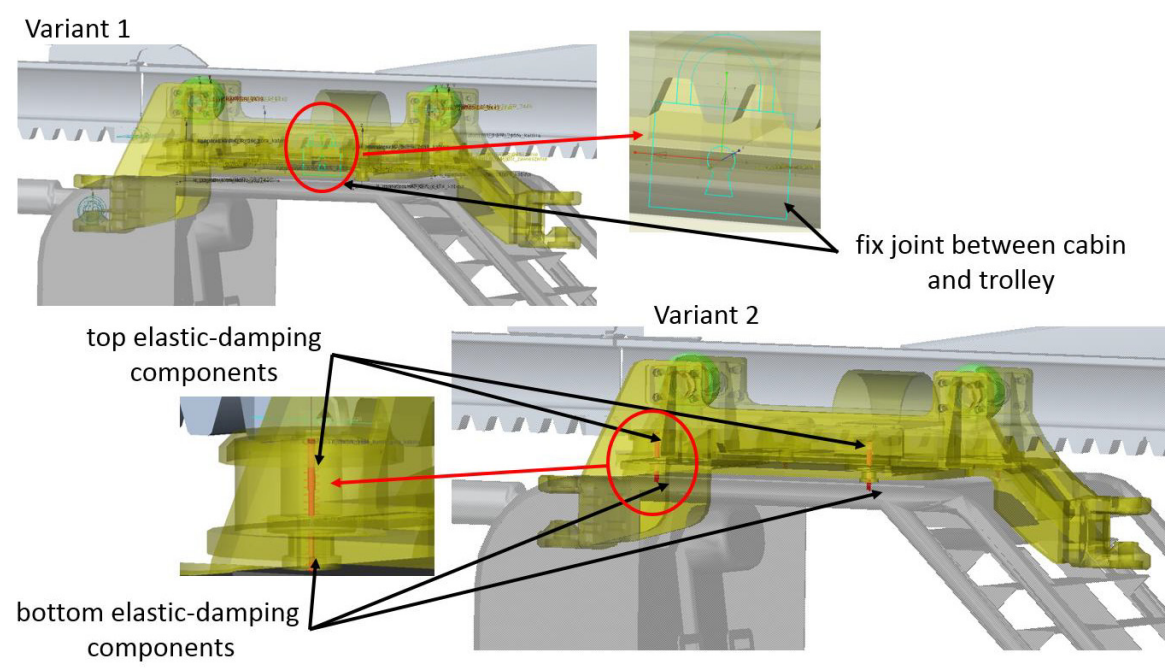

Fig. 2. Driver's cabin suspension method: variant 1 (top left), variant 2 (bottom right) (INESI, 2019)

At present, there are no yielding systems for suspending the cabins conveying passengers. The innovative method for suspending the passenger cabin was developed by Becker Warkop within the INESI project (INESI, 2019; Tokarczyk et al., 2019). In the computational model in Variant 1, the passenger cabin was rigidly connected to the supporting frame. In Variant 2, there is a possibility of moving the passenger cabin in relation to the load-bearing frame. This effect was achieved by the use of control arm system and implementation of elasticdamping components with the parameters selected by the cabin manufacturer. The elastic-damping components used in the computational model of passenger cabin had the stiffness of $1.189953 \cdot 10^{5} \mathrm{~N} \cdot \mathrm{m}^{-1}$ and the damping factor of $1900 \mathrm{Nsm}^{-1}$. The difference between Variant 1 and 2 regarding the passenger cabin is shown in Figure 3. 


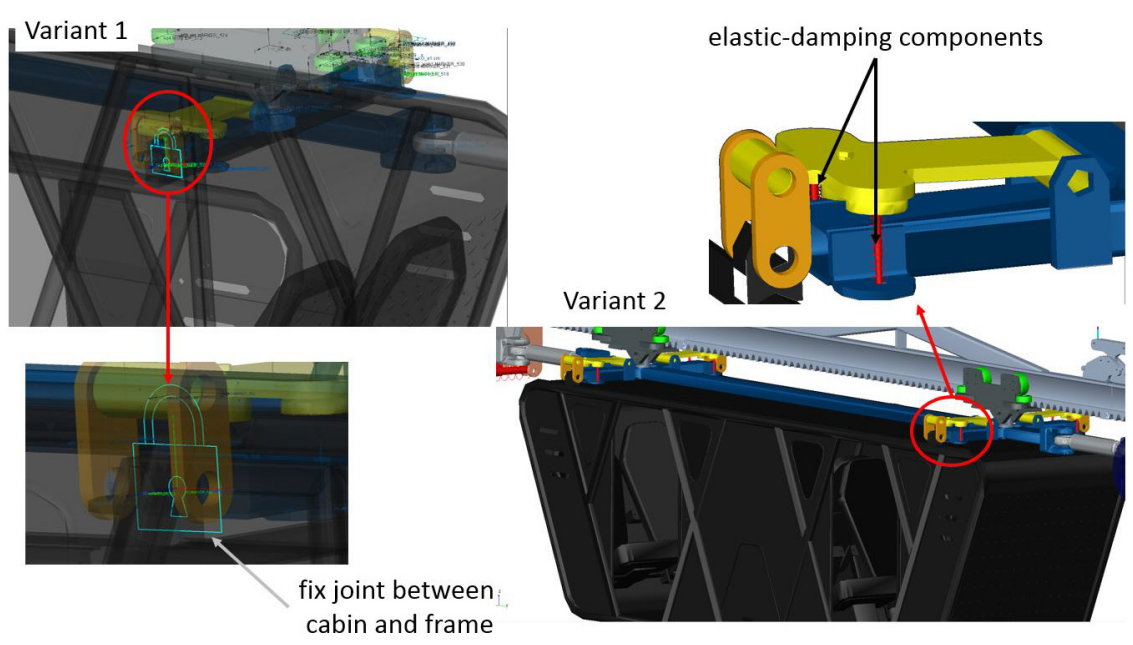

Fig. 3. Method for suspending the passenger cabin: Variant 1 (left), Variant 2 (right) (INESI, 2019)

The suspended monorail set is driven by two rack and pinion drives. In the computational model, the contact parameters between the gears and the rack on each rail were defined. The suspended monorail was accelerated to the set speed, after defining the torque applied to the gears in a drive. Displacements, accelerations of all components of the suspended monorail as well as forces and torques in the selected nodes, e.g. in the route suspensions, were recorded during the simulation.

\section{Simulation results}

With regard to both variants of the computational model, the suspended monorail movement along a straight track section was simulated. The simulation consisted of accelerating the suspended monorail to the set speed, and then passing through another rails without changing the travel speed. The acceleration stage of the suspended monorail lasted from 0 to $2 \mathrm{~s}$, then it moved at a speed of about $3.5 \mathrm{~m} / \mathrm{s}$. The velocity graph in the axis of travel (Y axis), as regards the driver's cabin in both variants, is presented in Figure 4. The graph shows regular cyclical speed disturbances occurring at regular intervals (Turygin et al., 2016). They result from passing through the joints of successive rails. The speed was measured at the place of operator's seat. The graph shows smaller speed disturbances in variant 2 simulations. This is the result of action of the elastic-damping components of the cabin suspension.

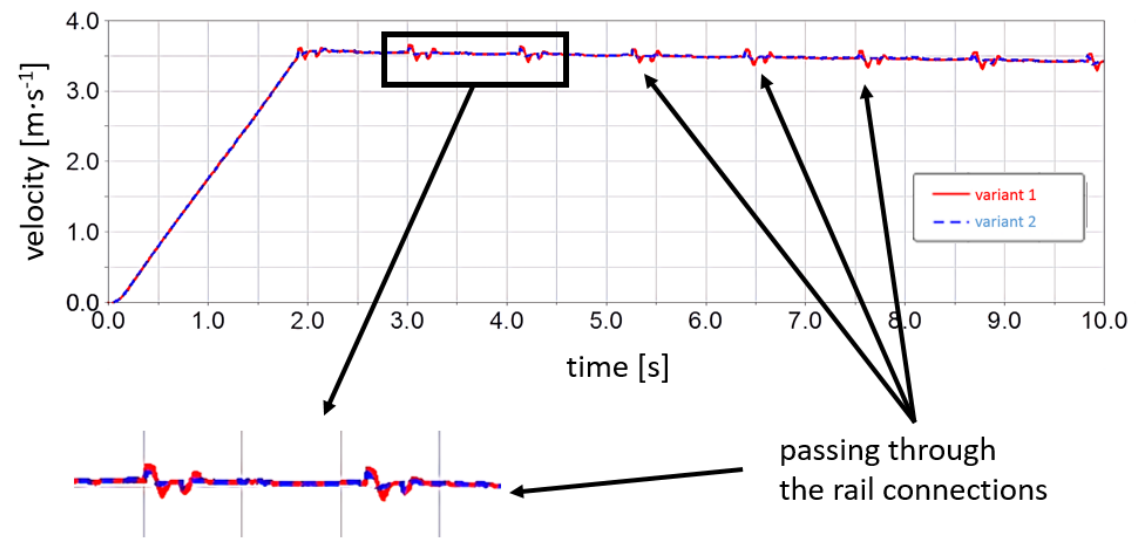

Fig. 4. Speed chart recorded during the travel simulation of operator's cabin (INESI, 2019)

Figures 5 - 7 show the acceleration graphs recorded in three axes of the coordinate system, on the operator's seat, during the simulation. The $\mathrm{X}$-axis is a horizontal axis perpendicular to the travel direction of the suspended monorail, the $\mathrm{Y}$-axis is the axis along travel direction, while the $\mathrm{Z}$-axis is a vertical axis. 


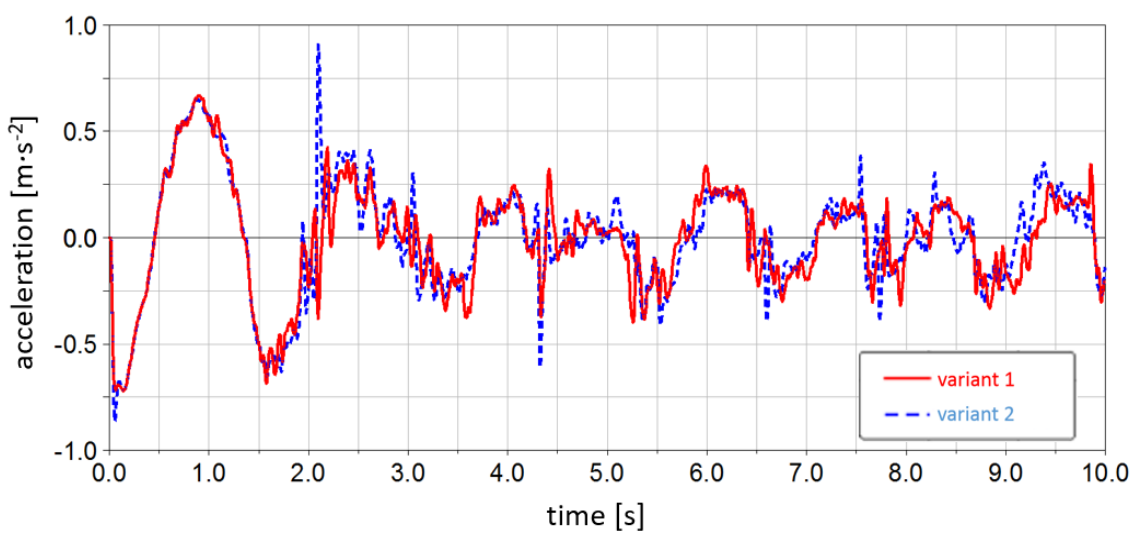

Fig. 5. Diagram of acceleration vs time recorded at the operator's seat in the X-axis (INESI, 2019)

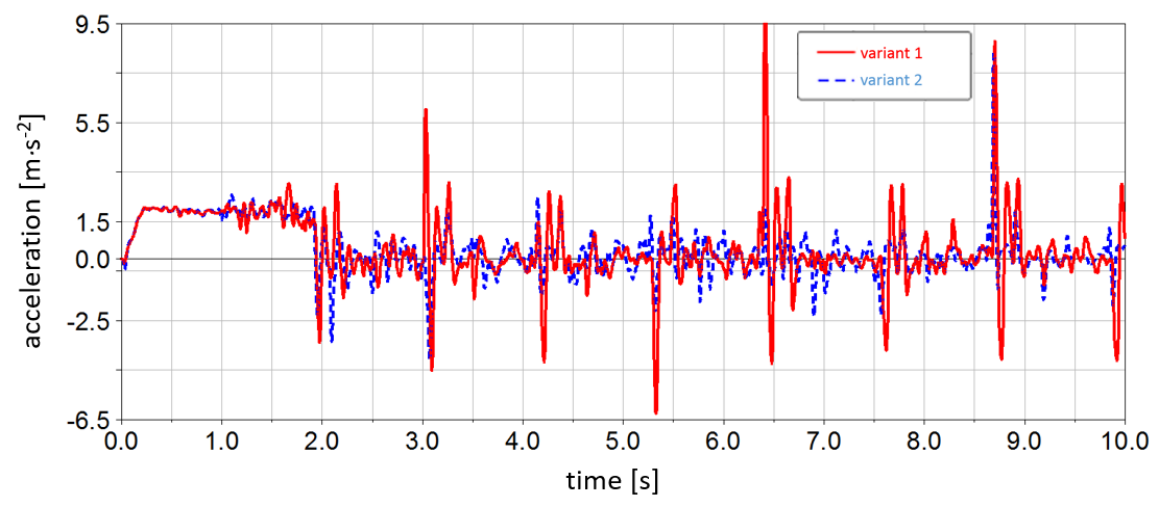

Fig. 6. Diagram of acceleration vs time recorded at the operator's seat in the Y-axis (INESI, 2019)

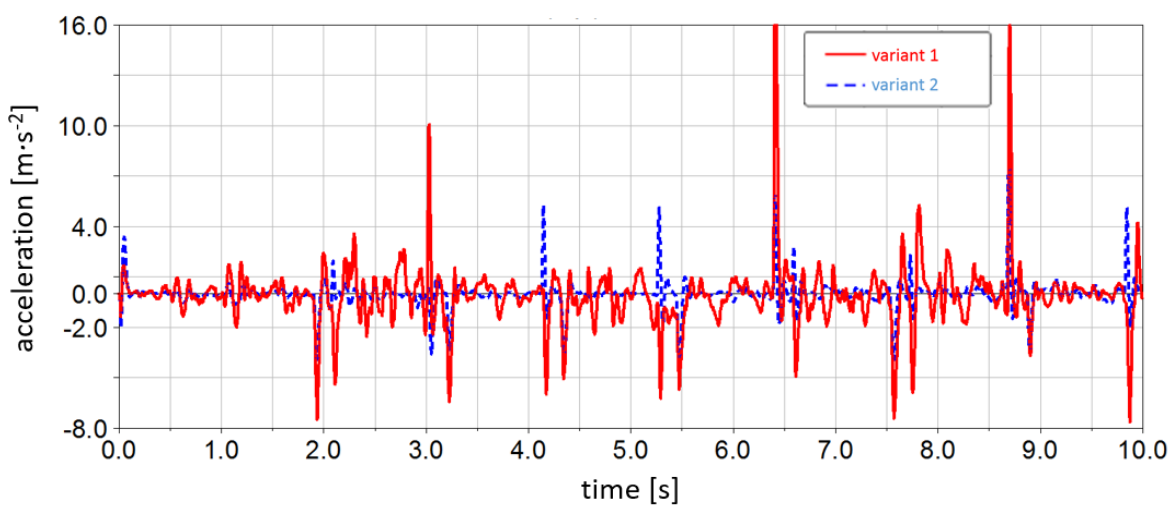

Fig. 7. Diagram of acceleration vs time recorded at the operator's seat in the Z-axis (INESI, 2019)

By analysing the acceleration curve on the operator's seat, it can be observed that in the X-axis in Variants 1 and 2, the accelerations on a similar level were recorded. In the other axes in variant 2, much lower accelerations were recorded compared to Variant 1 . This is especially evident when passing through the rail joints, which is represented by peaks in diagrams. It proves that the introduction of yielding components in the suspension of the operator's cabin has a positive effect on reducing the level of vibrations.

In the same way, accelerations in the passenger cabin were recorded, the result of these records is shown in Figures 8 - 10 . 


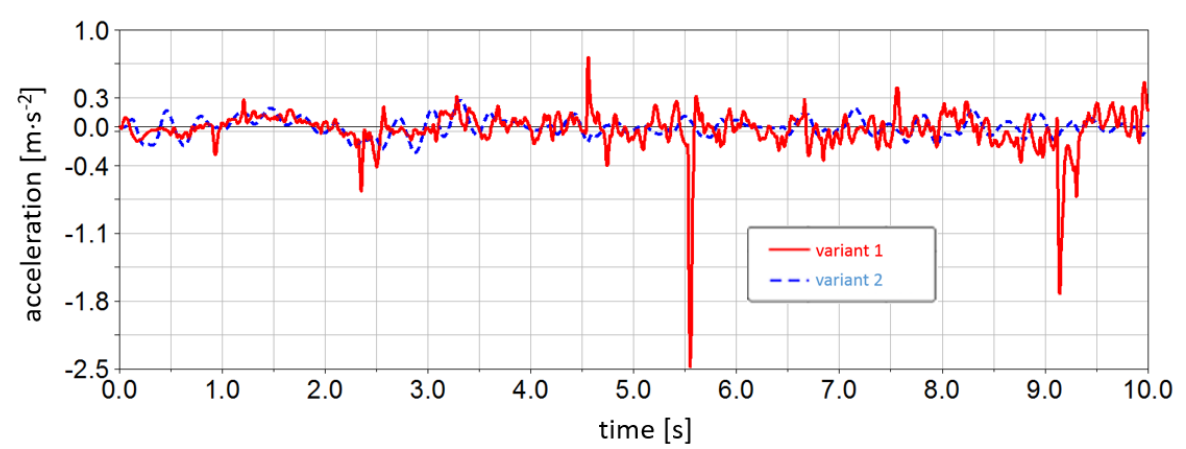

Fig. 8. Diagram of acceleration vs time recorded in the passenger cabin in the X-axis (INESI, 2019)

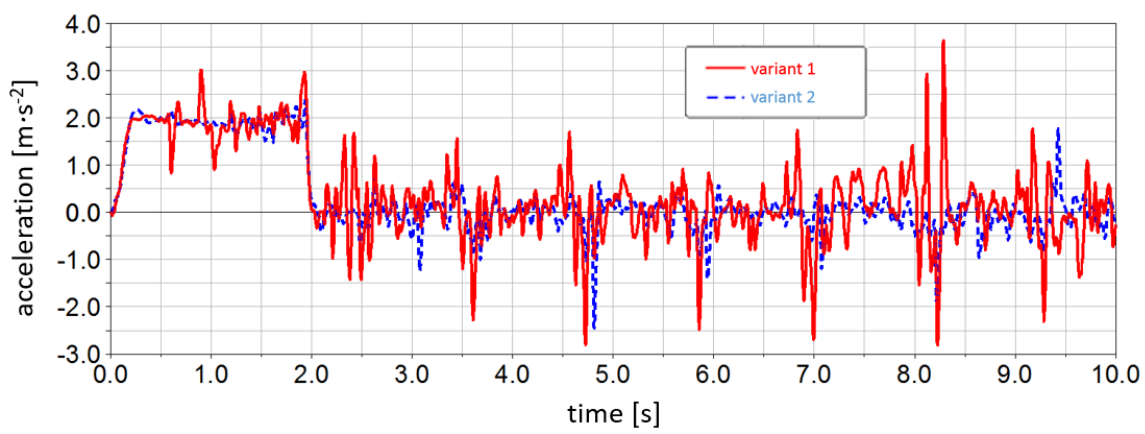

Fig. 9. Diagram of acceleration vs time recorded in the passenger cabin in the Y-axis (INESI, 2019)

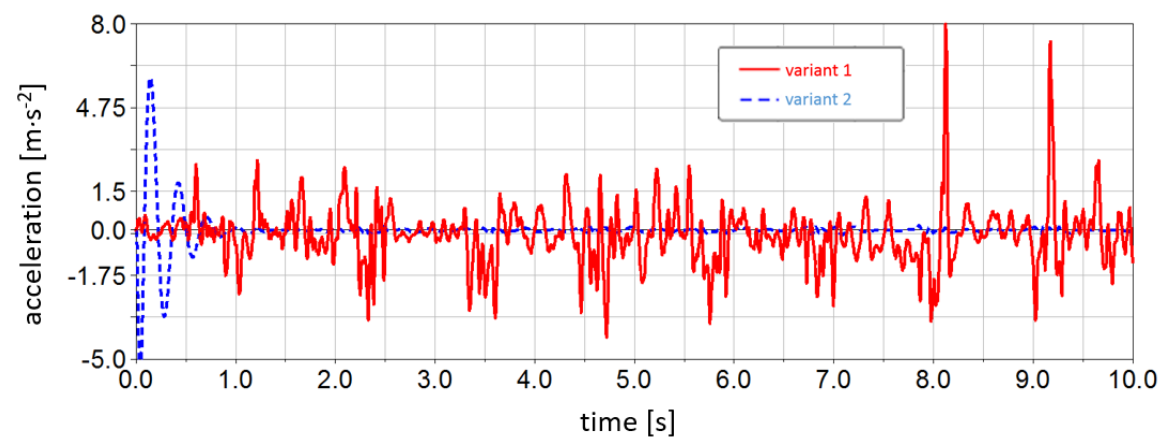

Fig. 10. Diagram of acceleration vs time recorded in the passenger cabin in the Z-axis (INESI, 2019)

As in the case of the operator's cabin, the use of a yielding suspension in the passenger cabin resulted in the reduction of accelerations recorded in Variant 2 in relation to accelerations recorded in Variant 1. In the case of passenger cabins, the reduction in accelerations was observed in all three axes.

The results presented in the diagrams were further analysed. Table 1 shows the root mean square (RMS) accelerations in three axes, both in relation to the operator's cabin and the passenger cabin. In addition, the RMS accelerations were determined in relation to the full simulation (acceleration and travelling stage) as well as limited only to the suspended monorail travelling stage with a set speed, neglecting the acceleration stage (time: 2-10s).

Table 1. Root mean square (RMS) accelerations in three axes in relation to the operator's cabin and the passenger cabin (INESI, 2019)

\begin{tabular}{|c|c|c|c|}
\hline  & $\begin{array}{c}\text { RMS of the X-axis } \\
{[\mathrm{m} \cdot \mathrm{s}-2]}\end{array}$ & $\begin{array}{l}\text { RMS of the Y-axis } \\
{[\mathrm{m} \cdot \mathrm{s}-2]}\end{array}$ & $\begin{array}{c}\text { RMS of the Z-axis } \\
{[\mathrm{m} \cdot \mathrm{s}-2]}\end{array}$ \\
\hline \multicolumn{4}{|c|}{ Operator's cabin } \\
\hline variant $1-$ full & 0.26 & 1.50 & 2.00 \\
\hline variant $1-2-10 \mathrm{~s}$ & 0.17 & 1.41 & 2.18 \\
\hline variant 2 - full & 0.27 & 1.11 & 0.86 \\
\hline variant $2-2-10 \mathrm{~s}$ & 0.18 & 0.82 & 0.89 \\
\hline \multicolumn{4}{|c|}{ Passenger cabin } \\
\hline variant $1-$ full & 0.21 & 1.03 & 1.13 \\
\hline variant $1-2-10 \mathrm{~s}$ & 0.23 & 0.68 & 1.21 \\
\hline variant $2-$ full & 0.09 & 0.88 & 0.69 \\
\hline variant $2-2-10 \mathrm{~s}$ & 0.09 & 0.35 & 0.06 \\
\hline
\end{tabular}


Then, according to the standard provisions (PN-EN 14253+A1:2011), daily vibration exposure (A(8)) was calculated. The calculations were made with the assumption of an 8-hour working day, during which the operator of the suspended monorail was exposed to vibrations in the cabin for 4 hours, while the time of exposure of the passenger in the passenger cabin was assumed to last for 2 hours. The results of the calculations are presented in Table 2 .

Table 2. Daily exposure to vibrations on the operator and passenger of the suspended monorail (INESI, 2019)

\begin{tabular}{|c|c|c|c|c|}
\hline & $\begin{array}{c}\operatorname{Ax}(8) \\
{[\mathrm{m} \cdot \mathrm{s}-2]}\end{array}$ & $\begin{array}{c}\operatorname{Ay}(8) \\
{[\mathrm{m} \cdot \mathrm{s}-2]}\end{array}$ & $\begin{array}{c}\mathrm{Az}(8) \\
{[\mathrm{m} \cdot \mathrm{s}-2]}\end{array}$ & $\begin{array}{c}\mathrm{A}(8) \\
{[\mathrm{m} \cdot \mathrm{s}-2]}\end{array}$ \\
\hline \multicolumn{5}{|c|}{ Operator's cabin (exposure time 4h) } \\
\hline variant $1-$ full & 0.25 & 1.49 & 1.42 & 1.49 \\
\hline variant $1-2-10 \mathrm{~s}$ & 0.17 & 1.39 & 1.54 & 1.54 \\
\hline variant $2-$ full & 0.26 & 1.09 & 0.6 & 1.09 \\
\hline variant $2-2-10 s$ & 0.18 & 0.8 & 0.64 & 0.8 \\
\hline \multicolumn{5}{|c|}{ Passenger cabin (exposure time $2 \mathrm{~h}$ ) } \\
\hline variant $1-$ full & 0.14 & 0.72 & 0.56 & 0.72 \\
\hline variant $1-2-10 \mathrm{~s}$ & 0.16 & 0.48 & 0.6 & 0.6 \\
\hline variant $2-$ full & 0.06 & 0.62 & 0.34 & 0.62 \\
\hline variant $2-2-10 \mathrm{~s}$ & 0.06 & 0.24 & 0.03 & 0.24 \\
\hline
\end{tabular}

In the case of Variant 1 during the full simulation (acceleration and travel stage), both in relation to the operator's cabin and the passenger cabin, the dominant influence on the human body is acceleration in the Y-axis (consistent with the direction of travel). The acceleration in the $\mathrm{Z}$ (vertical) axis is dominant when analysing the travel stage alone without the acceleration stage. The introduction of a yielding suspension in Variant 2 decreases the significance of accelerations acting in the $Z$ (vertical) axis. In the Variant 2 in both cases (with and without the acceleration stage) acceleration direction consistent with the Y-axis (consistent with the direction of travel) - the dominant direction.

Introduction of a yielding suspension significantly reduces the daily exposure to vibration by the suspended monorail operators and passengers. Significant reduction in exposure to vibration can be observed when analysing only the railway travel without the acceleration stage. In the case of analyses also covering the acceleration stage, the observed small improvement in the vibration exposure coefficient results from the acceleration in the $\mathrm{Y}$-axis required to speed up the suspended monorail.

\section{Discussion}

The analyses carried out, the results of which are given in the paper, were aimed at analysing the impact of the use of a flexible suspension of the operator's cabin and passenger cabin on the level of vibration acting on the operator and passengers. Due to health hazards associated with long-term exposure to vibrations, estimating its level - at the design stage, before building a prototype, is highly expected. As was shown in the article, it is possible to predict the level of vibration, based on the virtual model of the machine and suspension. An extremely important aspect of the analysis is the ability to change the mechanical properties of the suspension system elements and the observation of the impact of these changes on the level of vibration affecting the human travelling in the suspended monorail.

It is worth to mention, that vibration analysis on the stage of the virtual prototyping of the new machine design extends the range of simulated phenomena, related to the human factor. In a typical approach, analyses like an ergonomic assessment are focused on the analysis of the workplace dimensions (field of view, optimal reaching zones) and their influences on the operator's posture (static comfort coefficient). Extending simulation scope also to the vibration analysis, significantly brings virtual prototyping closer to reality.

Conducting the numerical simulations allowed for objective and quantitative comparison of two constructions of the operator's cabin. As a result of the analyses, it can be determined which of the cabs is safer and more comfortable for the operator. However, it should be taken into account that some simplifications in the carried out simulations were applied and they may affect the recorded accelerations (vibrations). The introduction of such simplifications was necessary to optimise the computational model construction and to reduce the simulation time. The computational model can accelerate in a slightly different way than the real object. It results from simplifications in the driving system, which were limited to defining the driving torque acting on the gear wheels. Neglecting the vibrations generated by the machinery part and engine part is another important simplification regarding the vibrations. This may cause discrepancies between the vibrations obtained in numerical simulation and measured on the real object. Other simplifications concern the operator's seat and the passenger seats. The calculation model does not take into account the material from which the seats are made, and thus their vibration damping characteristics were neglected. This fact, according to the authors, does not disqualify using the simulations for cognitive and comparative purposes in the analysis of vibrations generated during suspended monorail travel along a rail and rail joints, and from the possibility of analysis of 
vibration and overloading acting on the operator or passengers of the suspended monorail in emergency situations, such as emergency braking. The justification for the above statement is the fact that the vibrations presented in the article are mainly caused by passing through the route joints and unevenness of the route, as well as dynamic phenomena such as the process of accelerating and braking the transportation system. At the same time, the modification of the monorail suspension system is aimed at suppressing vibrations arising during the ride.

\section{Conclusions}

The discussed simulations were aimed at comparing the level of vibrations affecting the operator and passengers of the suspended monorail in the case of using a rigid connection between the operator's cabin and the passenger cabin with the trolley and cabins connected to the trolleys with a yielding suspension. The analyses of the results confirm the possibility of using numerical simulations to compare the impact of vibrations on men at their workplace. As it was suggested on the basis of the analyses, the yielding suspension of operator's and passenger cabins significantly improves the comfort of the operator's work and passenger travel. In addition, the use of numerical simulations allows analysis and comparison of vibration damping efficiencies using materials of different stiffness and damping coefficients. In this way, the optimal materials for manufacturing the yielding components of the cabin suspension can be selected. The simulations conducted at the design stage enable selecting the optimal materials, changing the maximum allowable deflections of the yielding suspension components or introducing changes to the assumed concept of the suspension system. The presented method of using numerical simulations to analyse the vibrations, acting on the operator, and passengers of the suspended monorail, together with the calculation of the daily exposure to vibrations, can also be implemented for the analysis of any machine. The use of the simulation software, and developed algorithm, allows estimating the amount of exposure of any machine operator to vibrations. With knowledge of the vibrations course and the possible overloads attributable to the operator, both at the design stage and as part of the modernisation of existing machines, develop a way to improve working conditions by reducing daily exposure to vibrations.

It should be noticed that too high vibration levels affect other parameters, such as dynamic overloads in the suspended route and in components of the transportation unit, as well as noise. The latter is particularly troublesome when it is generated in closed and limited spaces. It should be avoided if passenger transport takes place over long distances between the shaft and the crew's workplace. In addition, unsprung masses excited by vibrations of a certain frequency may, as a consequence, be a source of resonance, i.e. a rapid increase in the amplitude of their vibrations.

As part of future work, the authors plan to validate the calculation model by comparing the results of numerical analyses with the values recorded on the test track. The next step will be to analyse dynamic phenomena such as emergency braking at different speeds of the suspended monorail. Further simulations will be focused on the analysis of the impact of the suspended monorail speed on travelling comfort and safety of the monorail operator and passengers in normal conditions and in emergency situations.

\section{References}

AlShabi, M., Araydah, W., ElShatarat, H., Othman, M., Younis, M.B. and Gadsden, S.A. (2016) Effect of Mechanical Vibrations on Human Body. World Journal of Mechanics, 6, 273-304. doi: http://dx.doi.org/10.4236/wjm.2016.69022

Basri B., Griffin M.J. (2013) Predicting discomfort from whole-body vertical vibration when sitting with an inclined backrest. Appl. Ergon., 44, pp. 423-434

Bovenzi M. (2005) Health effects of mechanical vibration. Giornale italiano di medicina del lavoro ed ergonomia, 27:1, pp. 58-64

Bozek, P., Ivandic, Z., Lozhkin, A., Lyalin, V., Tarasov, V. (2016). Solutions to the characteristic equation for industrial robot's elliptic trajectories. In Tehnički Vjesnik - Technical Gazette. Vol. 23, iss. 4, pp. 10171023.

Budniok T., Zasadni W., Mrowiec H., Kania J., Rusinek J., Szymiczek K. (2014) Analiza możliwości zwiększenia prędkości jazdy ludzi kolejkami podwieszonymi z napędem własnym. Conference Proceedings: XXII Międzynarodowa Konferencja Trwałość Elementów i Węzłów Konstrukcyjnych Maszyn Górniczych, TEMAG 2014

Dz.U. 2018 poz. 1286 - Rozporządzenie Ministra Rodziny, Pracy i Polityki Społecznej z dnia 12 czerwca 2018 r. w sprawie najwyższych dopuszczalnych stężeń i natężeń czynników szkodliwych dla zdrowia w środowisku pracy

Harazin B. (2002) Zawodowa ekspozycja na ogólne wibracje w Polsce. Medycyna Pracy, Vol. 53, No. 6, p. 465472

INESI European Project: Increase Efficiency and Safety Improvement in Underground Mining Transportation Routes. RFCS, Contract No. 754169 (2017-2020) 
Issever H., Aksoy C., Sabuncu H., Karan A. (2003) Vibration and Its Effects on the Body. Medical Principles and Practice;12: pp.34-38. doi: 10.1159/000068155

Kiełbasa P., Dróżdż T., Wojtas D. (2019) Analiza drgań ogólnych i miejscowych na stanowisku pracy operatora specjalistycznej maszyny drogowej. Autobusy 1-2/2019. pp. 281 - 286 doi: 10.24136/atest.2019.051

Kiełbasa P., Juliszewski T., Smółka Ł., Zięba A. (2017) Ergonomiczna ocena środowiska Drganiowego istotnego z punktu widzenia komfortu pracownika i organizacji pracy wybranego procesu produkcyjno naprawczego. Autobusy 6/2017, p.242 - 246

Koradecka D. (1999) Bezpieczeństwo pracy i ergonomia Tom 2. Centralny Instytut Ochrony Pracy, Warszawa ISBN 83-91074-6-5

Kowalski P. (2019) Drgania mechaniczne. Zagrożenia i profilaktyka. Materiaty szkoleniowe Serwis Internetowy Bezpieczniej CIOP PIB: https://www.ciop.pl/CIOPPortalWAR/appmanager/ciop/pl?_nfpb= true \& pageLabel $=$ P620029861340177898311

Kowalski P., Zając J. (2012) Research on simultaneous impact of hand-arm and whole-body vibration, International Journal of Occupational Safety and Ergonomics (JOSE), Vol. 18, 1, s. 59-66

Kowalski P., Zając J. (2017) Influence of vertical and horizontal whole-body vibration on some psychomotor and cognitive functions of employees age 50+ (pilot study)., Journal of Vibroengineering, Vol. 19, Issue 3, p.2174-2179

Krajnak K. (2018) Health effects associated with occupational exposure to hand-arm or whole body vibration, Journal of Toxicology and Environmental Health, Part B, 21:5, 320-334, doi: $10.1080 / 10937404.2018 .1557576$

Lesiak K. Brzeżański M. (2018) Concept of the exhaust system for diesel engines used in underground mining. Conference proceedings: KONMOT 2018, International Automotive Conference, Kraków, pp. 1-6, ISSN 1757-899X

Muravev V.V., Muraveva O.V., Volkova L.V., Sága M., Ságová Z. (2019) Measurement of residual stresses of locomotive wheel treads during the manufacturing technological cycle. Management Systems in Production Engineering. Vol. 27, Issue 4. pp. 236-241. doi: 10.1515/mspe-2019-0037

Nędza Z., Gola S., Madeja -Strumińska B. (2006) Wczesna diagnostyka choroby wibracyjnej na stanowisku pracy w zakładach górnictwa skalnego. Mining Science, VIII(1): p.145-154

Pieczora E. Suffner H. (2017) Rozwój napędów dołowych kolejek podwieszonych. Maszyny Górnicze 20173 pp. 44-57, ISSN 2450-9442.

PN-EN 14253+A1:2011 Drgania mechaniczne. Pomiar i obliczenia zawodowej ekspozycji na drgania o ogólnym działaniu na organizm człowieka dla potrzeb ochrony zdrowia. Wytyczne praktyczne (Mechanical vibration - Measurement and calculation of occupational exposure to whole-body vibration with reference to health - Practical guidance).

Polnik B. (2018) An Innovative Power Supply System Dedicate for Roadheading Mining Machines. Conference proceedings: ABAF 2018, 19th International Conference on Advanced Batteries, Accumulators and Fuel Cells, Brno, 26-29 August 2018 349-362, ISSN 1938-6737

Szczepaniak Jan, Kromulski Jacek (2011) Analysis of energy flow model in the Biomechanical system human operator - agricultural combination. Journal of Research and Applications in Agricultural Engineering, Vol. 56(4)

Szewerda K. (2019) Supporting development of suspended underground monorails using virtual prototyping techniques. INNOVATIVE MINING TECHNOLOGIES (IMTech Scientific and Technical Conference) IOP Conf. Series: Materials Science and Engineering 545 (2019) 012018 IOP Publishing, doi: 10.1088/1757-899X/545/1/012018

Tokarczyk J., Michalak D., Rozmus M., Szewerda K., Żyrek L., Železnik G. (2019) Ergonomics Assessment Criteria as a Way to Improve the Quality and Safety of People's Transport in Underground Coal Mines. In: Rebelo F., Soares M. (eds) Advances in Ergonomics in Design. AHFE 2019. Advances in Intelligent Systems and Computing, vol 955. Springer, Cham, DOI: https://doi.org/10.1007/978-3-030-20227-9_28

Tokarczyk J. (2017) Methodology for identifying the selected mechanical hazards in auxiliary transport of underground mines, Monograph vol. 52, Institute of Mining Technology KOMAG, Gliwice

Tokarczyk J. Kania J. (2016) Systems and tracks of self-powerd suspended monorails for transportation of people in horizontal workings and workings with inclination up $45^{\circ}$. Mining Informatics, Automation and Electrical Engineering, Vol. 3, p.31-39.

Turygin, Y., Bozek, P., Abramov, I., Nikitin, Y. (2018) Reliability determination and diagnostics of a mechatronic system. In Advances in Science and Technology Research Journal. Vol. 12, iss. 2, pp. 274290.

Zasadni W., Kania J., Tokarczyk J., Rusinek j., Szymiczek K. (2015) Możliwości zwiększenia prędkości jazdy kolejkami podwieszonymi z napędem własnym. Conference proceedings: XVII Konferencja: Problemy bezpieczénstwa i ochrony zdrowia w polskim górnictwie. 